\title{
КАТЕГОРИЯ СУБЪЕКТИВНОГО И ПРОБЛЕМА СООТНОШЕНИЯ ВНЕШНЕГО И ВНУТРЕННЕГО У С. КЬЕРКЕГОРА
}

\author{
М.Г. ЧЕСНОКОВА ${ }^{\mathrm{a}}$
}

${ }^{a}$ Московский государственньй университет им. М.В. Ломоносова, 119991, Россия, Москва, Ленинские горы, д. 1

\begin{abstract}
Резюме
Статья представляет собой попытку определить место и значение идей С. Кьеркегора в общем контексте истории психологической науки. Обосновывается рассмотрение творчества С. Кьеркегора как самостоятельной оригинальной программы построения психологии, наряду с программами В. Вундта, Ф. Брентано, И.М. Сеченова. Подчеркивается роль экзистенциальной философии и психологии С. Кьеркегора как методологической платформы современной экзистенциальной психологии. Предметом исследования является понимание С. Кьеркегором категории субъективного. Раскрывается положение С. Кьеркегора о субъективном как «скрытом внутреннем» становящегося субъекта, а также его представление о характере связи внешнего и внутреннего. Концепция субъективного С. Кьеркегора сопоставляется с пониманием субъективного в классической интроспективной и объективной психологии. Дается сравнительный анализ решения проблемы соотношения внешнего и внутреннего в экзистенциальной психологии С. Кьеркегора и деятельностном подходе. Отмечаются как сходство - пафос внутреннего у С.Л. Рубинштейна, так и различия двух подходов, связанные с последовательным детерминизмом и общественноисторической трактовкой природы личности и индивидуальности у представителей деятельностного подхода. Разъясняется позиция С. Кьеркегора в вопросе о способе познания внутреннего Другого. Реконструируется характеристика особенностей субъективного и объективного мышления С. Кьеркегором, обосновывается важность различения этих двух типов мышления для психологии. Прослеживается связь идей С. Кьеркегора с актуальными тенденциями современной психологии - развитием качественной методологии, неклассической и постнеклассической парадигм в психологии, преодолением жесткого детерминизма в пользу принципа свободы, постулатом принципиальной неопределенности бытия и успешным развитием экзистенциальной психологии.
\end{abstract}

Ключевые слова: экзистенция, субъективность, внешнее и внутреннее, свобода, детерминизм, субъективное и объективное мышление, экзистенциальная психология, деятельностный подход.

\section{Творчество С. Кьеркегора в контексте истории психологии}

Творчество С. Кьеркегора слабо освещено в отечественной психоло- гической литературе. До последнего времени его имя фактически не упоминалось в научных исследованиях. Ярлык религиозного мыслителя, «тяжелый» философский язык, а 
также сложности с переводом его текстов (Кьеркегор писал по-датски) препятствовали обращению к его работам практически ориентированных психологов, предпочитавших знакомиться с экзистенциальной психологией по работам более поздних авторов: Л. Бинсвангера, М. Босса, В. Франкла, Р. Мэя, А. Лэнгле и др. Историки психологии также не проявляли большого интереса к идеям датского мыслителя. Несмотря на то что в философских кругах С. Кьеркегор давно признан родоначальником экзистенциализма, в анализе истоков развития экзистенциальной психологии, предлагаемом в известных учебниках по истории психологии, ссылки на С. Кьеркегора отсутствуют. В частности, в учебнике Т.Д. Марцинковской (2008), где экзистенциальной психологии посвящена целая глава, философия экзистенциализма представлена именами Э. Гуссерля, М. Хайдеггера, К. Ясперса и определяется как направление философской мысли XX в., неразрывно связанное с осмыслением социально-исторических реалий данной эпохи. Между тем методологическая платформа экзистенциализма и основной круг проблем формируются еще в XIX в. именно в работах С. Кьеркегора.

Есть и другая причина, побуждающая историков психологии обратить на идеи С. Кьеркегора более серьезное внимание. Концепция экзистенциальной философии и психологии С. Кьеркегора была выдвинута незадолго до появления первых программ построения психологии как самостоятельной науки В. Вундта, Ф. Брентано, И.М. Сеченова и при ближайшем рассмотрении несет в себе все основные черты такой программы. В ней есть свое особое понимание предмета психологии, стратегии и тактики психологического исследования (Чеснокова, 2014). И, на наш взгляд, она имеет все основания рассматриваться в истории становления психологической науки наряду с ними.

Не менее интересен историкофилософский контекст возникновения экзистенциальных взглядов С. Кьеркегора, развивавшихся фактически параллельно с философией марксизма. Как известно, советская психология ХХ в. в целом пошла по пути развития марксистской методологии. Западная же психология, в той своей части, которая сохранила связь с философией как основой психологического подхода к человеку, поколебавшись какое-то время между марксизмом и экзистенциализмом, пройдя через попытку синтеза двух методологий (Ж.-П. Сартр, Э. Фромм), в конечном счете из двух философских систем анализа бытия сделала выбор в пользу экзистенциализма. В настоящее время экзистенциальная психология представляет собой мощное практико-ориентированное течение в рамках гуманистической психологии. Марксистская же психология на Западе пользуется значительно меньшим влиянием. В то же время некоторые современные отечественные исследователи склонны усматривать в творчестве основоположников деятельностного подхода А.Н. Леонтьева и С.Л. Рубинштейна выраженную экзистенциальную направленность, усиливающуюся якобы в их поздних работах (Асмолов, 2003; Братусь, 2003; Василюк, 2003; Леонтьев, 2008, 2011; 
Субботский, 2003; и др.). Подобное утверждение несколько противоречит декларируемой ориентации деятельностного подхода на марксистскую методологию, а также прямой критике взглядов экзистенциалистов (в частности, М. Хайдеггера), встречающейся в работах С.Л. Рубинштейна. Вместе с тем оно побуждает к более глубокому исследованию природь и происхождения «экзистенциальных параллелей» в творчестве представителей деятельностного подхода. Историко-психологический анализ сущности экзистенциального мировоззрения, рассмотренного в его становлении, выявление его инвариантного ядра, а также совместимости и непротиворечивости его с марксистской методологией способствовали бы, на наш взгляд, прояснению этого вопроса.

Можно констатировать наличие веских оснований для обращения к анализу истоков экзистенциальной психологии в творчестве Серена Кьеркегора. Введение взглядов С. Кьеркегора в контекст истории психологической науки существенно меняет представление о логике ее развития. Экзистенциальная психология предстает уже не как направление новейшей психологии XX в., а как одна из исходных программ развития науки, которая по ряду причин была проигнорирована академической психологией. Весь путь развития психологической науки выступает тем самым в новом свете.

Данное утверждение требует аргументации. В последние годы появляются работы, авторы которых обращаются к разным аспектам взглядов С. Кьеркегора, используют его идеи для методологического обоснования собственных исследований (Иванченко, 2009; Ковалевская и др., 2011, 2012, 2013; Кривцова, 2013; Лелик, 2012; Чеснокова, 2013, 2014). В одной из своих предыдущих статей мы постарались раскрыть суть кьеркегоровской программы психологии, которую мы определили как качественный подход к психологии индивидуальности (Чеснокова, 2014). Понимание индивидуальности (Я) С. Кьеркегором существенно отличается от интерпретаций этого понятия, принятых в современной психологии, оно не имеет ничего общего и с так называемой психологией индивидуальных различий. В то же время оно сближается и даже отождествляется с другими значимыми категориями психологической науки, такими как субъективное и внутреннее. Целью данной статьи является содержательный анализ понятий субъективное, внутреннее и внешнее в работах С. Кьеркегора в сопоставлении с их классической и неклассической трактовкой в психологии.

\section{Развитие субъективности как становление «скрытого внутреннего» у С. Кьеркегора}

С. Кьеркегор известен как один из ярчайших полемистов своего времени. Его оппонентный круг был весьма широк. Однако его наиболее острая и неослабевающая критика была направлена против рационалистической философии. Картезианство и гегельянство способствовали, по его мнению, формированию у его современников иллюзии всемогущества «чистого мышления», развитию «абстрактной многосторонности», 
стремящейся обрести весь мир посредством одного лишь мышления. Дух объективизма и увлечение всемирно-историческим привели к тому, что в своем «многознании» люди потеряли самих себя. Они глубокомысленно рассуждают о множестве важных вещей - истории, политике, Боге и бессмертии, но они не живут на самом деле. Мышление стало их действительностью. Они забыли, что значит просто быть быть человеком.

С. Кьеркегор ставит вопрос о возвращении человеку самого себя, о ценности подлинного (а не иллюзорного, умозрительного) существования, о сложной, порой мучительной диалектике этого существования, о мужестве «самостояния» на пике экзистенции.

Человек сам несет ответственность за собственное существование в мире, которая не может быть передоверена ни философам, ни государству, ни другому индивиду, считает С. Кьеркегор. Это связано с тем, что проблемы человеческой экзистенции вообще не выражаются на языке абстракции, которым оперируют современная философия и наука. Абстрактное мышление пренебрегает всеми трудными ситуациями, в которые попадает экзистирующий индивид. Оно безразлично к конкретному человеку. Поэтому осмысление собственного существования было и остается задачей самого человека. Осуществление этой задачи требует от индивида перенесения взгляда извне вовнутрь, с познания мира на самого себя, превращения из бесстрастного объективного наблюдателя в заинтересованного субъективного мыслителя.
Важно, что кьеркегоровский призыв к индивиду стать субъективным звучал на фоне активного становления интроспективной психологии сознания, позиционирующей себя как индивидуальную субъективную психологию (программа психологии В. Вундта, как мы помним, включала в себя индивидуальную и культурноисторическую психологию народов). С. Кьеркегор же фактически выступает оппонентом этой субъективной психологии. Смысл этой оппозиции заложен в особенностях понимания субъективного С. Кьеркегором. Классическая интроспективная психология, выросшая на идеях Р. Декарта и Дж. Локка, подходила к проблеме субъективного гносеологически, понимая под ним некое содержание, представленное в сознании индивида (непосредственный опыт, по В. Вундту). При этом индивидуальные различия сознаний не принимались в расчет. Проблема собственной активности субъекта здесь также не стояла. В условиях интроспективного лабораторного эксперимента она просто элиминировалась. Субъект понимался только как мыслящий, сознающий, универсальный, тождественный самому себе (Я = Я). Это был субъект мысли, но не субъект жизни, существования. Даже у родоначальника психологии личности У. Джемса сущность личности сводилась к ее рефлексивной части и отождествлялась с мыслью.

Проблема субъекта активности была поставлена только объективной психологией. В.М. Бехтерев предложил рассматривать человека как активного деятеля в среде, эта идея была развита ленинградской психологической школой. С.Л. Рубинштейн 
первым в отечественной психологии заговорил о двух пониманиях субъективного:

1) как индивидуально-пристрастного представления о чем-либо (гносеологический аспект);

2) как принадлежащего определенному субъекту (онтологический аспект).

Он выделил три основных способа существования человека в мире:

1) деятельность;

2) познание;

3) эстетическое переживание и, соответственно, три типа субъектности. Представление о человеке как активном субъекте своей жизнедеятельности было развито ближайшими учениками С.Л. Рубинштейна А.В. Брушлинским и К.А. Абульхановой-Славской.

Понимание субъективного в работах С. Кьеркегора не совпадает ни с субъективной, ни с объективной его трактовкой в психологии. Субъективное у С. Кьеркегора подразумевает субъектность. Однако это субъект не внешнего, а внутреннего действия. И в этом принципиальное отличие кьеркегоровского понимания субъектности от ее объективного понимания. Субъективное, разъясняет он, есть скрытое внутреннее, $\partial y x$ и страсть. Страсть представляет собой высшее и наиболее полное выражение субъективности. Связывая субъективность со страстью, С. Кьеркегор выступает и против гносеологической интеллектуалистской трактовки субъективного, принятой в интроспективной психологии сознания. «Действительная субъективность - это вовсе не субъективность познающего... действительная субъективность - это субъ- ективность этически экзистирующая», - пишет он (Кьеркегор, 2012, c. 309).

Субъект С. Кьеркегора - мыслящий и существующий - не тождествен самому себе $(Я \neq Я)$. Это субъект становящийся. Его становление глубоко диалектично. Отправной точкой здесь служит противоречие, заключающееся в том, что собственная субъективность одновременно и дана, и не дана индивиду. Он по существу является субъектом, но он должен раскрыть себя как субъекта. Развитие субъективности идет от неистинной (не знающей, не принимающей себя) субъективности к действительной, истинной субъективности. Это также есть процесс все более полного определения собственного Я.

С. Кьеркегор отрицает какую бы то ни было объективную детерминированность такого определения. Более того, он утверждает, что рождение субъекта происходит как раз в условиях объективной неопределенности, когда индивид не имеет возможности опереться ни на что, кроме самого себя, в этом мире, когда он берет на себя ответственность, и именно это его внутреннее решение, находящее воплощение во внешних действиях, определяет развитие ситуации. Само внутреннее решение феноменологически представляет собой как бы отталкивание от всего внешнего (объективного), являясь актом изоляции при удержании одной значимой для индивида идеи. Сила такого решения дается страстью, вытекающей из глубокой личной заинтересованности индивида в положительном для него исходе. Таким образом, субъективность, по 
С. Кьеркегору, есть свободное проявление духа.

Антидетерминизм С. Кьеркегора шел вразрез с общей тенденцией психологической науки XIX-XX вв., ориентированной на активный поиск детерминант и принципа детерминации развития личности. В отечественной психологии вопрос об общем принципе детерминации личности являлся, в частности, предметом дискуссий А.Н. Леонтьева и С.Л. Рубинштейна. Согласно С.Л. Рубинштейну, внешние причины действуют опосредованно через внутренние условия. По А.Н. Леонтьеву, внутреннее действует через внешнее и этим себя изменяет. В течение длительного времени понятия решения, возможности, свободы и ответственности являлись отличительной чертой именно экзистенциальногуманистического мировоззрения в психологии. И только сравнительно недавно, в частности под влиянием новейших открытий в области физики, психологи начали широко обсуждать феномены разрыва детерминации, «точки бифуркации», неопределенности. Д.А. Леонтьев констатирует перестройку современной психологии личности на новые ориентиры: от необходимого к возможному (Леонтьев, 2011).

Слабой стороной признания внешней, в частности социокультурной, детерминации развития личности со времен Л.С. Выготского являлся вопрос о механизмах выхода индивида за рамки норм и образцов, предписываемых ему современной культурой, в область индивидуального творчества как двигателя этой культуры. Решение этого вопроса в современной отечественной психо- логии связывается с изучением закономерностей творческой деятельности, «надситуативной активности», индивидуального стиля деятельности и т.д. С. Кьеркегор задолго до названных исследований поставил вопрос о механизмах выхода индивида «за предель самого себя». Согласно С. Кьеркегору, становление субъективности происходит через движение ко все большей внутренней глубине на основе стремления к бесконечному. Понимание этого утверждения невозможно без обращения к религиозной стороне взглядов С. Кьеркегора.

Для христианина С. Кьеркегора человек есть существо, представляющее собой единство конечного и бесконечного. Становление субъективности есть постоянное преодоление собственной конечности и стремление к бесконечному - к Богу. На этом пути человек проходит ряд стадий:

• осознания своей ограниченности, конечности как чего-то негативного;

- отчаяния;

- смирения;

- веры в то, что с Богом все возможно;

- решимости сделать то, что в силу естественной ограниченности разум оценивает как невозможное;

- остановки рефлексии и «прыжка» в экзистенцию;

- преобразования собственной субъективности и обретения нового качества.

Оставляя в стороне религиозный аспект данных представлений, нельзя не отметить глубину феноменологического анализа того, что С. Кьеркегор называл решением или внутренним действием субъекта. Не 
вызывает сомнения также ценность размышлений и феноменологических описаний С. Кьеркегора для исследований в области психологии религии. Речь идет, в частности, о его оценке роли образа Божия как высшего идеала человечности в процессе преодоления человеком самого себя, своей эмпирической данности, а также образа Христа как образа пути обретения этого идеала - «Христос есть путь».

Становление субъективности не есть что-то внешнее по отношению к мышлению - эмпирическая данность, осознаваемая задним числом по мере ее оформления. Это внутренний, глубоко рефлексивный процесс, считает С. Кьеркегор. Становление субъективности - путь субъективно$2 о$ мыслителя. На каждом поворотном пункте своего существования, принимая то или иное решение, субъективный мыслитель стремится осознать, кто он есть и кем он становится. Предметом его рефлексии являются не состояния и переживания сознания, как это имело место в интроспективной психологии, а он сам, его Я, его собственная субъективность.

\section{Проблема соотношения внешнего и внутреннего в экзистенциальной психологии С. Кьеркегора}

Неотъемлемой частью концепции субъективности (Я) как внутреннего у С. Кьеркегора является решение им вопроса о характере связи внешнего и внутреннего. Вопрос о соотношении внешнего и внутреннего относится к числу сквозных проблем психологии, к рассмотрению которых психологическая наука обращается снова и снова. На разных этапах развития науки проблема внешнего и внутреннего выступала:

- как проблема различения предмета психологии (внутренний опыт) и естественных наук (внешний опыт);

- как проблема противоположности сознания и поведения, среды и личности;

- как проблема взаимосвязи физического мира и его психического отражения, психических и физиологических процессов, сознания и деятельности;

- как проблема соотношения природного и социального в человеке, культурно обусловленного и индивидуального, детерминированного и «спонтанейного» и т.д.

Проблема внешнего и внутреннего и сегодня лежит в основе скрытого противоборства феноменологической, метафизической и объективной, экспериментальной психологии. Если психология XIX в. в целом развивалась под влиянием унаследованного от Р. Декарта и Дж. Локка параллелизма внешнего и внутреннего, то психология ХХ в. поставила вопрос о роли внешнего в формировании внутреннего.

В отечественной психологии можно выделить две наиболее фундаментальные разработки проблемы возникновения внутреннего. Это конкретно-психологическая концепция происхождения внутреннего на основе механизма интериоризации линия, развивавшаяся Л.С. Выготским, А.Н. Леонтьевым, П.Я. Гальпериным. И философски обоснованное представление С.Л. Рубинштейна, определяющего внутреннее как «итог предшествующего развития» (Рубинштейн, 1973). Если сторонники 
принципа интериоризации подчеркивали прямое влияние внешнего на внутреннее, что отразилось в тезисе А.Н. Леонтьева о единстве строения внешней и внутренней деятельности, то С.Л. Рубинштейн настаивал на самобытности внутреннего как «специфического преобразования внешних воздействий» (Там же). В качестве высшей формы внутреннего С.Л. Рубинштейн рассматривал личность, сила которой способна противостоять самым разрушительным воздействиям внешнего мира. Этот пафос внутреннего, пронизывающий последнюю работу С.Л. Рубинштейна «Человек и мир», образует невидимую нить, связывающую экзистенциальные мотивы в творчестве С.Л. Рубинштейна с идеями С. Кьеркегора - родоначальника экзистенциальной философии. Однако проведение прямых параллелей между экзистенциальным и деятельностным подходом в психологии требует более серьезного обоснования, чем простая аналогия и внешнее сходство взглядов. С этой точки зрения, на наш взгляд, принципиальным вопросом, на основании решения которого можно судить о близости или методологической разнородности двух подходов, является оценка ими роли деятельности в становлении субъекта, личности, индивидуальности.

Позиция представителей деятельностного подхода в вопросе о роли деятельности в развитии личности вполне однозначна и определенно заявлена С.Л. Рубинштейном еще в ранней его работе «Принцип творческой самодеятельности»: личность не просто проявляется, но созидается и определяется в деятельности
(Рубинштейн, 1986). Деяние входит в построение самого субъекта. При этом речь идет, прежде всего, о внешней практической деятельности как генетически первичной. И в этом суть деятельностного подхода. В его основе лежит примат деятельности над личностью, которая в противном случае превращается, по словам С.Л. Рубинштейна, в «пучок» или «связку» представлений. По мнению С. Кьеркегора, рождение человеческой субъективности происходит не во внешнем, но во внутреннем действии. Развертывание ее во внешнем плане вторично. Он пишет: «Внешним проявлением действия Лютера было то, что он вышел к ратуше в Вормсе, однако начиная с того самого момента, когда он со всей cmpacmной решимостью субъективности начал экзистировать в этом желании... - с этого мгновения он уже начал действовать... Утверждение о том, что решение, принятое во внешнем мире, важнее решения во внутреннем, - это достойная презрения болтовня слабых, трусливых и хитрых людей» (курсив мой. - М.Ч.) (Кьеркегор, 2012, с. 333).

Механизм становления внутреннего С. Кьеркегор видит не во взаимодействии с внешним (внутреннее действует через внешние условия А.Н. Леонтьев, внутреннее опосредует внешнее - С.Л. Рубинштейн), а, напротив, в отталкивании от внешнего и внутренней изоляции, в результате которой и достигается внутреннее углубление.

Отношение внешнего и внутреннего, по С. Кьеркегору, подчиняется не столько принципу тождества (принцип единства строения внешней и внутренней деятельности А.Н. Леонтьева), 
сколько принципу противоположности. Эта противоположность проявляется как на уровне соотношения духовного и телесного - «внутренняя глубина духа всегда кажется чем-то посторонним и чужим для тела» (Там же, с. 234), так и на уровне поведения, деятельности, образа жизни. Чем меньше внешнего, тем больше внутреннего, замечает С. Кьеркегор. Внутреннее без внешнего - самое трудное внутреннее. Легко поклоняться Богу, отгородившись от всего мира в монастыре, развивает он свою мысль. Значительно сложнее постоянно удерживать в себе мысль о Боге, соотнося с ней каждое даже самое незначительное свое действие во внешнем мире. Последнее есть путь углубления своей внешней деятельности. Оно выражается в том, как, каким образом человек делает нечто. Это «как» и есть способ существования внутреннего.

Отношение внешнего и внутреннего глубоко диалектично. Выражением этой диалектики является то, что на разных уровнях существования соотношение внешнего и внутреннего меняется. Так, совпадение внешнего и внутреннего свойственно, по мнению С. Кьеркегора, только первой, начальной стадии развития человеческого духа - эстетической. На втором уровне - этическом уже закладывается противоположность внешнего и внутреннего. Наконец для третьей - религиозной стадии характерно противостояние внешнего и внутреннего.

В зависимости от того, на какой стадии развития находится человек, одна и та же манера поведения может иметь разное внутреннее содержа- ние. Именно это внутреннее содержание и составляет подлинную действительность субъекта. Поворот к внутреннему содержанию мы находим и в рассуждениях С.Л. Рубинштейна о необходимости психологической интерпретации внешней деятельности, а также в разработанном А.Н. Леонтьевым методе смыслового анализа деятельности.

Особое внимание С. Кьеркегор уделяет проблеме выражения внутреннего. Так, он утверждает, что использование «готовых доступных форм повадки и поведения, слов и заверений» ведет к искажению внутреннего, которое в результате этого становится неистинным. Прямое выражение внутреннего (декларирование своих убеждений или рассказ о пережитом) также не может служить достаточным доказательством того, что соответствующее внутреннее содержание действительно имеется. Тем самым С. Кьеркегор выступает против как классического интроспективного, так и вульгарно объективного (о внутреннем нельзя судить по внешнему) способов познания внутреннего.

Адекватной формой выражения внутреннего, по мнению С. Кьеркегора, является так называемая косвенная форма сообщения, строящаяся на противоположности внешнего и внутреннего. Примером такой косвенной внутренне противоречивой формы духовного послания может служить эпизод из жизни С. Кьеркегора - разрыв помолвки при наличии глубоких чувств к покинутой девушке. Контрастность, внутренняя напряженность посылаемого сообщения является выражением внутренней глубины. Интересно, что 
идея косвенного характера представления внутреннего вновь возникает лишь в ХX в. в работах Л.С. Выготского, выдвинувшего представление о косвенном методе познания психического как реконструкции внутреннего по его следам во внешнем мире.

Внутренняя глубина - это то, что реально разделяет людей и делает невозможным прямое общение между ними, утверждает С. Кьеркегор. Форма сообщения как обращения к внутреннему другого человека должна быть построена таким образом, чтобы на ее основе можно было действовать. Сообщение должно открывать возможность для действия, которой человек может воспользоваться или не воспользоваться, по своему усмотрению. Через открытие этой возможности он присваивает внутреннюю реальность собеседника, его способ существования, его «как». Это присвоение происходит через развитие и преобразование собственной субъективности (своего внутреннего). Так, С. Кьеркегор связывает познание с действием, но не с рядовым действием, а с таким, в котором субъект с необходимостью выходит за предель себя. Познание не умозрительно, подчеркивает С. Кьеркегор. Оно действенно. Но это действие особого рода. Хотя оно и связано или может быть связано с деятельностью во внешнем плане, однако его суть составляет создание новой внутренней действительности субъекта. Отсюда вывод С. Кьеркегора: субъективность и есть истина (Кьеркегор, 2012). Это истина бытия субъекта, а не одного только мышления.

Таким образом, внутреннее для С. Кьеркегора имеет абсолютный приоритет перед внешним. Внешняя деятельность независимо от ее объективного результата не имеет никакой ценности, если она не сопровождается ростом и углублением внутреннего. Внешняя форма является только предпосылкой такого роста. «Внешнее - это зов трубы, который заставляет нас предпринять великое усилие» (Там же, с. 372). Наличие готовой внешней формы подчас затрудняет осознание того, что задача (обретение внутреннего содержания) не решена, а только поставлена. В этом случае субъект должен пройти этап преодоления формы ради обретения содержания. По сравнению с этим ситуация, когда внутреннее рождение субъекта и его готовность к действию предшествуют его развертыванию во внешнем мире, субъективно оказывается для индивида даже более легкой, поскольку внешнего, которое нужно преодолевать, еще нет, оно еще только может быть создано. В отечественной психологии проблема присвоения знаний и культурных форм поведения была поднята Л.С. Выготским, исследования продолжили А.Н. Леонтьев, П.Я. Гальперин, Д.Б. Эльконин и др. Однако задолго до них С. Кьеркегор показал, что внешнее поведение, деятельность, слово, - по сути, не более чем знаки, за которыми может стоять как нечто большее, так и меньшее по сравнению с тем, что явлено.

Сопоставительный анализ взглядов С. Кьеркегора и представителей деятельностного подхода (С.Л. Рубинштейна и А.Н. Леонтьева) выявляет определенные параллели в решении проблемы соотношения внешнего и внутреннего в экзистенциальной 
и деятельностной парадигмах. Однако различия двух подходов, на наш взгляд, более принципиальны. Определим два основных момента.

Центральным понятием экзистенциальной философии является понятие существования (экзистенuии). Причем речь идет о существовании внутреннего - субъективного, Я, индивидуальности, которое у С. Кьеркегора противопоставляется существованию индивида во внешнем мире. Становление внутреннего составляет суть, дух и жизнь, подлинную действительность человека. Никакие внешние достижения преобразование мира, интеллектуальная деятельность, творчество и т.д. не имеют значения, если при этом человек утратил свое внутреннее, потерял самого себя или, хуже, никогда и не был собой. Внутреннее, субъективное, индивидуальное обладает для экзистенциального философа единственной неоспоримой ценностью. Внешнее есть только повод для раскрытия внутреннего. Деятельностный подход имеет совершенно иную ценностную ориентацию. В ее основе лежит признание общественной и исторической значимости личности, которая, таким образом, оценивается, прежде всего, через ее объективные достижения. Подлинное существование личности для деятельностной психологии состоит в ее деятельности, общественной по своей природе. «Личность тем значительнее, чем больше ее сфера действия, тот мир, в котором она живет, и чем завершеннее этот последний, тем более завершенной является она сама... Завершенная индивидуальность не значит изолированная единичность» (Ру- бинштейн, 1986, с. 107). Однако именно во внутренней изоляции рождается индивидуальность, по С. Кьеркегору. И способность удерживать свое внутреннее при всех перипетиях внешнего существования, не распыляясь в нем, является условием обретения своего Я перед Богом и перед миром. Борьба с собой за самого себя составляет основной пафос экзистенциальных размышлений С. Кьеркегора.

Деятельностный подход в психологии базируется на принципе детерминизма. Конкретные формулировки этого принципа (С.Л. Рубинштейн, А.Н. Леонтьев) могут различаться учетом в них роли и «удельного веса» внутреннего, однако это не отменяет исходной посылки - признания факта детерминации внутреннего. По С. Кьеркегору, внутреннее не имеет внешней детерминации. Рождение субъективности (Я) для самого человека обусловлено только его собственной решимостью быть, существовать в этом мире как единичному и неповторимому, являть миру свое Лицо. И это решение представляет собой свободное выражение духа. Развитие индивидуальности - это не подготовленное, внешне обусловленное движение, это всегда риск и вызов, в том числе своей собственной детерминации. Используя терминологию С. Кьеркегора, можно сказать, что позиция деятельностного подхода соответствует этическому, а позиция самого С. Кьеркегора - религиозному мировоззрению.

Развитие экзистенциализма в ХХ в., несомненно, изменило облик этого учения, придав ему новые черты. Возник атеистический экзистенциализм 
(Ж.-П. Сартр). Однако основные постулаты экзистенциализма (ценность индивидуальности, принцип свободы и ответственности человека за свое существование, «экзистенция» как живой момент деятельности, взятый субъективно, и др.) остались прежними. И это вынуждает с большой осторожностью сопоставлять деятельностный и экзистенциальный подходы в психологии и тем более говорить об их родстве.

\section{Субъективный мыслитель против объективного наблюдателя}

Особо стоит остановиться на той стороне взглядов С. Кьеркегора, которая отличает его философию от близких экзистенциализму течений философской мысли, таких как философия жизни и феноменологический подход. Отличие это заключается в том, что, несмотря на резкую критику систем рационализма, растворивших индивида в неотвратимой логике развития истории и духа, С. Кьеркегор не обесценивает человеческую способность мыслить, осмыслять действительность. Его субъект - это не декартовский субъект мышления, но и не дильтеевский субъект переживания. Субъект С. Кьеркегора - это субъект, существующий и осмысляющий свое существование. Переживания страха, страдания, отчаяния, вины и т.д. в его понимании ценны не сами по себе, а как знаки, сигнализирующие о переломных моментах внутреннего движения, становления субъективности. Человек должен не растворяться в своих переживаниях, а проходить их насквозь, не созерцать, а принимать решения, не наблюдать за жизнью внешней или внутренней, а жить. Критерием подлинного существования является не столько полнота переживания настоящего, сколько движение вперед, качественное преобразование самого себя, своей субъективности. Собственное Я, считает С. Кьеркегор, должно стать первейшим объектом заботы человека. Рефлексия процесса становления собственного Я составляет суть особого - субъективного мышления. С. Кьеркегор подробно анализирует особенности субъективного мышления, его отличия от объективного (научного) мышления (Кьеркегор, 2012). Они заключаются в следующем.

Объективное мышление безразлично к субъекту познания. Предметом размышлений субъективного мыслителя является само его существование.

Объективное мышление - это всегда некий разговор о чем-то, отличном от себя. Ядро субъективного мышления составляет внутреннее действие, акт самоопределения, происходящий через соотнесение и приведение себя в соответствие с определенной идеей. Так, одно дело рассуждать о том, что есть добро, другое - самому совершить добрый поступок.

Объективное мышление пытается понять конкретное абстрактным образом. Субъективное мышление стремится понять абстрактное конкретно. Подлинной индивидуальностью, по мнению С. Кьеркегора, является не тот, кто противопоставляет себя и свою жизнь общечеловеческим ценностям, но кто наиболее полно воплощает их собой и своей жизнью.

Объективное мышление общезначимо. Свидетельством истинности 
той или иной идеи является количество ее приверженцев. Субъективное мышление является актом изоляции. Первым шагом субъективного мыслителя является отказ от поиска готовых ответов, помощи наставников и проводников на пути к истине. Субъективного мыслителя отличает «диалектическое бесстрашие», проявляющееся в решимости остаться один на один со своей проблемой.

Объективное мышление нацелено на получение результата. Субъективное мышление - это становящееся мышление становящейся субъективности (Я).

Результаты объективного мышления легко отчуждаются от субъекта познания и могут быть переданы другому в словесной форме. Формальная передача объективной истины на словах не играет существенной роли, если воспринимающий ее индивид никак не меняется под ее влиянием, считает С. Кьеркегор. Истину можно считать усвоенной только тогда, когда ученик в своем мышлении и существовании проделал путь, аналогичный тому, который прошел до него учитель.

Объективное мышление передает знания. Субъективное мышление способ существования.

Внешняя форма объективной мысли легко может быть скопирована. Субъективное мышление абсолютно индивидуально. Понять субъективность другого - значит принять его способ существования как возможность для себя (и я могу жить и поступать так же). Присвоить чужую субъективность - значит реализовать ее способ существования в своей жизни, повторить ее путь в своих обстоятельствах.
Объективное мышление исходит из того, что знание истины автоматически ведет к ее присвоению. Объективная истина - категория мышления, сознания. Сутью субъективного мышления является приведение себя, своей жизни в соответствие с истиной. Достижение этого соответствия и есть присвоение истины. А обретение такого соответствия сама субъективная истина. Одно только знание объективной истины не гарантирует ее присвоения. Более того, сам способ ее присвоения может быть как истинным (достижение субъективной истины), так и ложным, утверждает С. Кьеркегор.

Рефлексия объективного мышления в принципе бесконечна. Она не имеет прямого выхода в действие, в наличное существование. Чтобы осуществить что-то во внешнем мире, рефлексия должна быть прервана, процесс мышления остановлен. Оставаясь же внутри мышления как такового, человек, по мнению С. Кьеркегора, способен мыслить только проилое. Настоящее он может мыслить только в «снятом» виде. Систематизация, к которой стремится объективное мышление, возможна только по отношению к тому, что уже обрело свою завершенность. То, что само находится в процессе становления, систематизировано быть не может.

В отличие от объективного, субъективное мышление, связанное с решением и действием, относится именно к наличному существованию. Оно обращено не к прошлому, а к будущему, определяя, кем я как человек становлюсь в результате этого действия.

Объективное мышление не может развиваться внутри противоречия. 
Оно стремится либо «снять», либо объяснить его. Однако, как отмечает C. Кьеркегор, фактически такое объяснение оборачивается лишь попыткой свести реальное противоречие к чему-то другому, отличному от него, иначе говоря, показать, что никакого противоречия здесь вообще нет.

Субъективное мышление только и рождается в условиях объективного противоречия наличного существования (например, нечто крайне привлекательное для меня может быть достигнуто мной только путем причинения ущерба другим). Необходимость продолжать существование требует от индивида преодоления - «прохождения» этого противоречия «насквозь». Размышляя об одном, он должен постоянно удерживать в сознании его противоположность, соединяя их внутри своего существования.

Критерий объективности знания ставит мышление выше чувств, веры и действия, которые уже вторично получают свое определение посредством мышления. В сфере экзистенции (здесь и сейчас), которой подчинено субъективное мышление, все эти элементы наличествуют одновременно.

Объективное мышление беспристрастно. Оно исходит из противоположности аффекта и интеллекта, делая выбор в пользу последнего. Субъективное мышление строится на противоречии между страстной заинтересованностью индивида в собственном существовании и объективной неопределенностью (порой невозможностью) этого существования, фиксируемой разумом. В этом противоречии аффекта и интеллекта и рождается вера как основа решения и действия индивидуального субъекта.

Объективное мышление как общезначимое всегда стремится обрести внешнюю доступную для всех форму выражения. Субъективное мышление неразрывно связано с преобразованием субъекта, обретением внутренней глубины при минимуме внешних проявлений.

Анализ особенностей субъективного и объективного мышления, осуществленный С. Кьеркегором, обладает, на наш взгляд, несомненной ценностью для психологии. Современная психология хорошо знает различия между теоретическим и практическим интеллектом (исследования Б.М. Теплова). Субъективное мышление С. Кьеркегора наряду с признаками практического мышления (связь с решением и действием) имеет свои неповторимые черты, связанные с необходимостью соотнесения внешних событий с собой и своим существованием в контексте общего становления собственной субъективности, что одновременно придает этому мышлению прогностический и ярко выраженный творческий характер. Неслучайно С. Кьеркегор сравнивает человеческую жизнь с созданием произведения искусства. В противоположность гносеологической трактовке субъективного мышления, имеющего критерием соответствие объективной истине, С. Кьеркегор показывает, что индивидуальность субъекта - это не просто ничего не значащий довесок к универсальной способности человека мыслить, а то, что собственно и развивается одновременно и в зависимости от того, 
как человек мыслит. Кьеркегоровский анализ специфики субъективного мышления заставляет по-новому взглянуть на историю психологической науки и переосмыслить некоторые оценки и представления, утвердившиеся в ней. В частности, иначе оценить место и значение так называемой субъективной (интроспективной) психологии. Если принимать логику С. Кьеркегора и его понимание сущности субъективного мышления, то придется признать, что психология XIX в., по сути, никогда и не была по настоящему субъективной наукой, поскольку даже внутренние состояния сознания она пыталась рассматривать и анализировать объективно, безотносительно к их роли в жизни человека, в процессе его самоосуществления. Как и объективная наука, она стояла на позиции бесстрастного наблюдателя, а не заинтересованного субъективного мыслителя. В современной методологии эта метапозиция нейтрального наблюдателя рассматривается как отличительная особенность классического типа рациональности, которая преодолевается в неклассическом и постнеклассическом типах мышления. Однако, как мы видим, дух неклассичности возникает в философской психологии значительно раньше, чем это принято полагать, и развивается параллельно с утверждением классической интроспективной парадигмы в психологии.

Рассуждения С. Кьеркегора о различиях субъективного и объективного мышления позволили ему выйти на ряд проблем, к которым научная психология обратилась только в XX в. Это проблема абстрактности и нежизнеспособности общей психо- логии, изучающей абстрактные способности абстрактного индивида (критика А.Р. Лурии, Л.С. Выготского, Ж. Политцера). Это также проблема присвоения научного знания (исследования Л.С. Выготского, А.Н. Леонтьева, П.Я. Гальперина, В.В. Давыдова), проблема отношения аффекта и интеллекта (исследования К. Левина, Л.С. Выготского), проблема отношения знания и веры (христианская психология) и др.

Анализ становления человеческой субъективности и специфики субъективного мышления имеет важное значение в контексте констатируемого в науке схизиса академической и практической психологии (Василюк, 1996). Присутствие живой человеческой субъективности составляет неустранимый момент, который отличает работу практического психолога от исследовательской деятельности академического психолога и теоретика. Работая с клиентом, практический психолог всегда имеет дело с человеком переживающим, страдающим и отчаивающимся, стремящимся осмыслить свое существование и верящим в лучшее будущее для себя. При этом практический психолог имеет дело не просто с сознанием клиента, но с целостным человеком. Критерием успешности терапии является обретение клиентом того внутреннего стержня и способности к самостоянию, о которой и писал С. Кьеркегор. На наш взгляд, схизис академической и практической психологии во многом проистекает из различия их исходных ориентаций - академической психологии на объективное мышление, а практической психологии на субъективное мышление 
клиента. Методологическое осмысление представлений С. Кьеркегора о двух типах мышления - объективном и субъективном, возможно, позволит лучше понять как эту, так и другие проблемы и тенденции современной психологии.

\section{Выводы}

В течение длительного времени вклад С. Кьеркегора в историю психологической науки неоправданно игнорировался. Его идеи оставались как бы на периферии генеральной линии развития психологии. Критика рационализма и религиозная окраска его идей, непривычный диалектический способ рассуждения, как будто нацеленный на максимальное усложнение решения рассматриваемых проблем, заземленность в конкретику и интерес к отдельному индивиду в ускользающе противоречивой диалектике его становления с самого начала определили оппозиционное положение С. Кьеркегора по отношению к оформляющейся психологии, складывающейся как эмпирическая, антидиалектическая, абстрактная наука о сознании. Неприятие С. Кьеркегором философской основы интроспективной психологии, прежде всего системы Р. Декарта, возможно, стало одной из главных причин невосприимчивости психологии к его идеям на ранних этапах развития науки. Однако, пройдя мимо экзистенциальной философии С. Кьеркегора, академическая научная психология упустила ряд ценных идей, на которые она смогла выйти лишь спустя значительное время, столкнувшись с серьезными противоречиями, кризисами и расколом внутри науки. И сегодня отсутствие должной представленности творчества С. Кьеркегора в картине истории развития психологии искажает наше понимание логики ее развития. Многие актуальные тренды современной психологии (развитие качественной методологии, неклассической и постнеклассической парадигм в психологии, преодоление жесткого детерминизма в пользу принципа свободы, постулат принципиальной неопределенности бытия, а также успешное развитие экзистенциальной психологии) заложены в неклассических экзистенциальных воззрениях С. Кьеркегора. На фоне этих тенденций мы высоко оцениваем тот факт, что психологическая наука в начале XXI в., хоть и с большим запозданием, обращается к небесспорным, но, безусловно, интересным для психологии идеям диалектически мыслящего философа XIX в. Серена Кьеркегора.

\section{Литература}

Асмолов, А. Г. (2003). Неодеятельностная парадигма в мышлении XXI века: деятельность как существование. Мир психологии, 2(34), 155-158.

Братусь, Б. С. (2003). Логотерапия как искусство быть. В кн. А. Лэнгле, Жизнь, наполненная смыслом: Прикладная логотерапия (с. 5-13). М.: Генезис.

Василюк, Ф. Е. (1996). Методологический смысл психологического схизиса. Bопросы психологии, 6, 25-40. 
Василюк, Ф. Е. (2003). «Вы понимаете...». Журнал практического психолога, 1-2, 232-240.

Иванченко, Г. В. (2009). Забота о себе: история и современность. М.: Смысл.

Ковалевская, О. Б., Лызлов, А. В., Серавина, О. Ф. (2011). Тревога как ядерный аффект: опыт структурно-психологического анализа. Вопросы психологии, 4, 66-77.

Ковалевская, О. Б., Лызлов, А. В., Серавина, О. Ф. (2012). Тоска как ядерный аффект: опыт структурно-психологического анализа. Вопросы психологии, 5, 62-72.

Ковалевская, О. Б., Лызлов, А. В., Серавина, О. Ф. (2013). Апатия как ядерный аффект: опыт структурно-психологического анализа. Вопросы психологии, 2, 65-79.

Кривцова, С. В. (2013). Диалог в ситуации провокации: беседуем по Кьеркегору. Экзистенциальная традищия: философия, психология, психотерапия, 1(22), 54-62.

Кьеркегор, С. (2012). Заключительное ненаучное послесловие $\kappa$ «Философским крохам». М.: Академический Проект.

Лелик, А. (2012). Архипелаг Кьеркегора. Экзистенциальная традищия: философия, психология, психотерапия, 1(20), 30-40.

Леонтьев, Д. А. (2008). Теория личности А.Н. Леонтьева. Режим доступа: http://www.psychologyonline.net/articles/doc-961.html/2008/02

Леонтьев, Д. А. (2011). Новые ориентиры понимания личности в психологии: от необходимого к возможному. Вопросы психологии, 1, 3-27.

Марцинковская, Т. Д. (2008). История психологии: Уиебник. М.: Издательский центр «Академия».

Рубинштейн, С. Л. (1973). Человек и мир. Проблемы общей психологии. М.: Педагогика.

Рубинштейн, С. Л. (1986). Принцип творческой самодеятельности. Вопросы психологии, 4, 101-107.

Субботский, Е. В. (2003). «Алексей Николаевич... фактически был экзистенциалистом в советской психологии». Журнал практического психолога, 1-2, 181-198.

Чеснокова, М. Г. (2013). Значение идей С. Кьеркегора для теории и практики психологии индивидуальности (к 200-летию С. Кьеркегора). Вопросы психологии, 5, 102-109.

Чеснокова, М. Г. (2014). Методологическое значение идей С. Кьеркегора в контексте развития психологической науки. Психология. Журнал Высшей школь экономики, 11(2), 120-135.

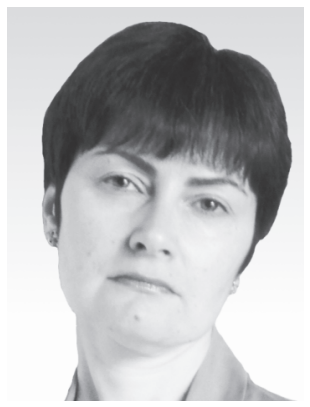

Чеснокова Милена Григорьевна - старший научный сотрудник, факультет психологии, Московский государственный университет имени М.В. Ломоносова, кандидат психологических наук.

Сфера научных интересов: история и методология психологии, психология индивидуальности, психология здоровья.

Контакты: milen-ches@bk.ru 


\title{
The Category of the Subjective and the Issue of the Relation of the External and the Internal in S. Kierkegaard
}

\author{
M.G. Chesnokova \\ ${ }^{a}$ Lomonosov Moscow State University, 1 Leninskie Gory, Moscow, 119991, Russian Federation
}

\begin{abstract}
The article poses an attempt to define place and meaning of S. Kierkegaard's ideas in the general context of history of psychological science. The justification is made for understanding the works by S. Kierkegaard as an independent, original program of psychology, along with the programs by W. Wundt, F. Brentano, I.M. Sechenov. The role of existential philosophy and psychology of S. Kierkegaard is underlined as a methodological platform of the modern existential psychology. The subject of the study is the understanding by S. Kierkegaard of category 'subjective'. The thesis by S. Kierkegaard is explored about the subjective as the 'inner hidden' of the becoming subject, as well as his notion about the characteristic of the relationship between the outer and the inner. The conception of the subjective by S. Kierkegaard is compared with the understanding of the subjective in the classic introspective and objective psychology. The comparative analysis is given for the problem of correspondence between the outer and the inner in S. Kierkegaard's existential psychology and in activity approach. Similarity (the pathos of the inner by S.L. Rubinstein) and differences of both approaches are noted, associated with consistent determinism and socio-historical understanding of the nature of personality and individuality in works by representatives of activity approach. The S. Kierkegaard's position is clarified on the issue of method of cognition of the inner Other. The S. Kierkegaard's characteristics of subjective and objective thinking is reconstructed, the importance for psychology of differentiation between these two types of cognition is substantiated. The relationship of S. Kierkegaard's ideas with topical tendencies of the modern psychology is traced: with the development of qualitative methodology, non-classical and post-non-classical paradigms in psychology, with overcoming of strict determinism in favor of principle of freedom, postulate of principal uncertainty of being and successful development of existential psychology.
\end{abstract}

Keywords: existence, subjectivity, inner and outer, freedom, determinism, subjective and objective thinking, existential psychology, activity approach.

\section{References}

Asmolov, A. G. (2003). Neodeyatel'nostnaya paradigma v myshlenii XXI veka: deyatel'nost' kak sushchestvovanie [Neoactivity paradigm in the XXI century thinking: Activity as existence]. Mir Psikhologii, 2(34), 155-158.

Bratus, B. S. (2003). Logoterapiya kak iskusstvo byt' [Logotherapy as art of being]. In A. Längle, Zhizn', napolnennaya smyslom: Prikladnaya logoterapiya [Life, filled with meaning: Applied logotherapy] (pp. 5-13). Moscow: Genezis. 
Chesnokova, M. G. (2013). Importance of S. Kierkegaard's ideas for the theory and practice of psychology of individuality (towards the 20-th anniversary of S. Kierkegaard). Voprosy Psikhologii, 5, 102-110.

Chesnokova, M. G. (2014). Methodological importance of the ideas of S. Kierkegaard for the development of psychological science. Psychology. Journal of the Higher School of Economics, 11(2), 120-135. (in Russian)

Ivanchenko, G. V. (2009). Zabota o sebe: Istoriya i sovremennost' [Self-care: History and modernity]. Moscow: Smysl.

Kierkegaard, S. (2012). Zaklyuchitel'noe nenauchnoe posleslovie k "Filosofskim krokham" [Concluding unscientific postscript to "Philosophical fragments"]. Moscow: Akademicheskii Proekt.

Kovalevskaya, O. B., Lyzlov, A. V., \& Seravina, O. F. (2011). The anxiety as a nuclear affect: An experience of structural-psychological analysis. Voprosy Psikhologii, 4, 66-77.

Kovalevskaya, O. B., Lyzlov, A. V., \& Seravina, O. F. (2012). Longing as a nuclear affect: An attempt at a structural psychological analysis. Voprosy Psikhologii, 5, 62-72.

Kovalevskaya, O. B., Lyzlov, A. V., \& Seravina, O. F. (2013). Apathy as a nuclear affect: A structural psychological analysis. Voprosy Psikhologii, 2, 65-79.

Krivtsova, S. V. (2013). Dialog v situatsii provokatsii: beseduem po K'erkegoru [A dialog in situation of provocation: a Kierkegaard's talk]. Ekzistentsial'naya Traditsiya: Filosofiya, Psikhologiya, Psikhoterapiya, 1(22), 54-62.

Lelik, A. (2012). Arkhipelag K'erkegora [Kierkegaard's archipelago]. Ekzistentsial'naya Traditsiya: Filosofiya, Psikhologiya, Psikhoterapiya, 1(20), 30-40.

Leontiev, D. A. (2008). Teoriya lichnosti A.N. Leontieva [A.N. Leontiev's theory of personality]. Retrieved from http://www.psychology-online.net/articles/doc-961.html/2008/02

Leontiev, D. A. (2011). New reference points for understanding personality in psychology: From the necessary towards the possible. Voprosy Psikhologii, 1, 3-27.

Martsinkovskaya, T. D. (2008). Istoriya psikhologii:uchebnik [History of psychology: A textbook] (8th ed., revised). Moscow: Izdatel'skii Tsentr "Akademiya".

Rubinstein, S. L. (1973). Chelovek i mir. Problemy obshchei psikhologii [A man and the world: Issues of general psychology]. Moscow: Pedagogika.

Rubinstein, S. L. (1986). Printsip tvorcheskoi samodeyatel'nosti [The principle of creative self-activity]. Voprosy Psikhologii, 4, 101-107.

Subbotsky, E. V. (2003). "Aleksei Nikolaevich... fakticheski byl ekzistentsialistom v sovetskoi psikhologii" [Aleksey Nikolaevich... actually was an existentialist in the Soviet psychology]. Zhurnal Prakticheskogo Psikhologa, 1-2, 181-198.

Vasiliuk, F. E. (1996). Metodologicheskii smysl psikhologicheskogo skhizisa [Methodological sense of psychological schisis]. Voprosy Psikhologii, 6, 25-40.

Vasilyuk, F. E. (2003). "Vy ponimaete..." [“Do you understand..."]. Zhurnal Prakticheskogo Psikhologa, $1-2,232-240$.

Milena G. Chesnokova - senior research fellow, Faculty of psychology, Lomonosov Moscow State University; Ph.D.

Research areas: history and methodology of psychology, psychology of individuality, health psychology.

E-mail: milen-ches@bk.ru 